\title{
Nursing higher education in MERCOSUR: a bibliometric study
}

\author{
A formação superior em enfermagem no MERCOSUL: um estudo bibliométrico
}

La formación superior en enfermería en el MERCOSUR: un estudio bibliométrico

\begin{abstract}
$+1$
Joanara Rozane da Fontoura Winters', Marta Lenise do Prado', Daniele Delacan Lazzari', Vanessa Luiza Tuono Jardim"

' Universidade Federal de Santa Catarina. Florianópolis, Santa Catarina, Brazil.

"Instituto Federal de Educação Ciência e Tecnologia de Santa Catarina. Florianópolis, Santa Catarina, Brazil.

How to cite this article:

Winters JRF, Prado ML, Lazzari DD, Jardim VLT. Nursing higher education in MERCOSUR: a bibliometric study. Rev Bras Enferm [Internet]. 2018;71(Suppl 4):1732-9. [Thematic Issue: Education and teaching in Nursing]

DOI: http://dx.doi.org/10.1590/0034-7167-2017-0405

Submission: 06-09-2017 Approval: 07-12-2017

\section{ABSTRACT}

Objective: to identify productions that approach nursing high education in member states of MERCOSUR. Method: bibliometric study with quantitative approach carried out in search mechanisms, such as BVS, Capes, SciELO, Scopus and PubMed, between 2006 and 2015. It was found 301 articles about nursing education in MERCOSUR. Results: point to concern for the nurse's education for public health policies, for teacher's education and the teaching-learning process. However, publications regarding technologies associated with distance education on health field are low. Conclusion: this study contributes with discussion in nursing education field when points to the themes regarding the production about nurses' education in MERCOSUR, specially, the range of targets set up in the Educational MERCOSUR agreement.
\end{abstract}

Descriptors: Nursing; MERCOSUR; Nursing Education; Higher Education; Bibliometrics.

\section{RESUMO}

Objetivo: identificar as produções que abordam a formação superior em enfermagem nos países integrantes do MERCOSUL. Método: estudo bibliométrico com abordagem quantitativa realizado nos mecanismos de busca BVS, Portal de Periódicos da Capes, SciELO, Scopus e PubMed, no período de 2006 a 2015. Foram encontrados 301 artigos acerca da formação em Enfermagem no MERCOSUL. Resultados: apontam para a preocupação com a formação do enfermeiro para as políticas de saúde pública, para a formação docente e o processo ensino aprendizagem, porém são tímidas as publicações em relação às tecnologias associadas à educação à distância na área da saúde. Conclusão: este estudo contribui com a discussão no campo da educação em enfermagem, ao apontar os temas sobre a produção acerca formação do profissional de enfermagem no MERCOSUL em especial, do alcance das metas estabelecidas no acordo MERCOSUL Educativo.

Descritores: Enfermagem; MERCOSUL; Educação em Enfermagem; Educação Superior; Bibliometria.

\section{RESUMEN}

Objetivo: identificar las producciones que abordan la formación superior en enfermería en los países integrantes del MERCOSUR. Método: estudio bibliométrico con abordaje cuantitativo realizado en los mecanismos de búsqueda BVS, Portal de Periódicos de la Capes, SciELO, Scopus y PubMed, en el período de 2006 a 2015. Fueron encontrados 301 artículos acerca de la formación en Enfermería en el MERCOSUR. Resultados: apuntan a la preocupación por la formación del enfermero para las políticas de salud pública, para la formación docente y el proceso de enseñanza aprendizaje, pero son tímidas las publicaciones en relación a las tecnologías asociadas a la educación a distancia en el área de la salud. Conclusión: este estudio contribuye con la discusión en el campo de la educación en enfermería, al apuntar los temas sobre la producción acerca de la formación del profesional de enfermería en el MERCOSUR en especial, del alcance de las metas establecidas en el acuerdo MERCOSUR Educativo.

Descriptores: Enfermería; MERCOSUR; Educación en Enfermería; Educación Universitaria; Bibliometria. 


\section{INTRODUCTION}

The Treaty of Asunción in 1991 stablished the Common Market of South (MERCOSUR) aiming to consolidate political, economic and social integration among its members, strengthen the links between citizens of the bloc and help improve their quality of life ${ }^{(1)}$. Among the proposed actions to enhance the links among MERCOSUR members states, is the free movement of people, promoting integration, dissemination and exchange of culture and knowledge.

In 1991, the Education Sector of MERCOSUR (SEM) ${ }^{1}$, was created by the Common Market Council, through Decision 07/91 to the MERCOSUR Meeting of Education Ministers (RME), which consist of entity in charge of coordinate the educational local policies $^{(1)}$. The sector plays an important role in this process of integration and mobility, what help the integration in the members of MERCOSUR ${ }^{(2)}$. In health field, the political and economic integration influence in education and qualification of professionals, such as nurses, that requires curriculum equalization and professional regulation.

In 2001, the Common Market Council (CMC), through decision 15/01, approved the "Organizational Structure of the MERCOSUR Education Sector", thus creating the Regional Coordination Committee, the Area Coordinating Regional Commissions (Basic, Technical and Superior) and the Information and Communication System Management Committee. In 2005, the Advisory Committee for MERCOSUR's Educational Fund was created. The Network of National Accreditation Agencies and the Regional Commission for the Coordination of Teacher Training was created in 2006 and 2011, respectively. There are other agencies besides these, temporary and permanent, that manage specific actions ${ }^{(1)}$.

The mission of MERCOSUR Education Sector is:

To set up a common education space, through the coordination of policies articulating education and the MERCOSUR integration process, by promoting the mobility, exchange and building of regional identity and citizenship, with the aim of achieving quality education for all, with special emphasis on the vulnerable sectors within a development process that fosters social justice and respect for the cultural diversity of peoples in the region ${ }^{(1)}$.

So, the investigation becomes required and relevant, aiming to identify gaps in the literature and can promote discussions about the process of nursing education. It improves the creation of new knowledge for the field and subsides public policies of education and health, considered under the MERCOSUR.

In view of these considerations, the question of the research is: What has been produced regarding the nursing education in members states of MERCOSUR for the last 10 years?

\section{OBJECTIVE}

To identify productions about nursing professional education in member states of MERCOSUR and the main themes approached.

\section{METHOD}

Bibliometric study with quantitative approach, carried out through a literature review. For Figueiredo ${ }^{(3)}$, bibliometrics is as a "statistical analysis of the processes of written communication, quantitative treatment (mathematical and statistical) of properties and behavior of registered information". It is, therefore, the use of mathematical and statistical techniques to analyze, in an objective way, the scientific production.

For Araújo ${ }^{(4)}$, bibliometrics has as main milestones of its development: "Lotka's method to measure the productivity of scientists (1926), Bradford's law of scattering of scientific knowledge (1934) and Zipf's law of distribution and frequency of words in a text (1949)". These are three classic laws of bibliometrics. By Lotka's law, has the productivity of authors; by Bradford's law, the journals productivity; by Zipf's law, the frequency of keywords.

It was held a gather of scientific production about the theme of the study in MERCOSUR's member states (Argentina, Brazil, Paraguay, Uruguay and Venezuela) and associated members (Bolivia, Chile, Colombia, Ecuador, Peru, Guyana and Suriname), available at search mechanism, such as BVS, Capes, SciELO, Scopus and PubMed. Data were collected between February and March of 2016.

The strategies of search were different for each of the basis, meeting its features. The terms were based on the dictionary of keywords of DeCS (Health Science Descriptors), applying Boolean operators. The inclusion criteria were: full articles, original research, reflection, experience statement and review; in Portuguese, English and Spanish, published between 2006 and 2015. The exclusion criteria were: texts that did not approached the scope of this bibliometrics, texts in duplicity and studies not fully available for analysis.

The search of article for the primary research was in February and March of 2016 in the search mechanism BVS, SciELO, PubMed, Capes and Scopus, through the following keywords: formação OR graduação OR "nível superior" OR undergraduate OR graduación OR degree OR formacion OR curricul* OR curriculum) AND (enfermagem OR enfermeria OR nursing) AND (Mercosul OR mercosur OR "Mercado Comum do Sul" OR "Mercado Común del Sur" OR "Common Market of the South" OR Brasil OR Brazil OR Argentina OR Paraguai OR Paraguay OR Uruguai OR Uruguay OR Equador OR Ecuador OR Chile OR Peru OR Colombia OR Venezuela OR Bolivia OR Suriname OR Guiana.

Is this first search were found 431 articles. After the reading, were excluded 130 articles in duplicity. The data corpus consisted of 301 articles. The references of the articles were transferred to the bibliographic manager EndNote Web and arranged in folders by data base. All documents were saved in folders as PDF (Portable Document Format). During the searches, the VPN (Virtual Private Network) of the Universidade Federal de Santa Catarina (UFSC) was used to reach a higher number of articles.

After the second reading, the data, extract just from the abstracts, were arranged in spreadsheet of Microsoft Excel, consisting

1 For further information access http://www.edu.mercosur.int/pt-BR/ 
of the following information: article title, authors, data base, journal, year of publication, country where the article was written, descriptors and keywords, type of publication (research/original article, experience statement, reflection or review), research sort (quantitative, qualitative or mixed), theoretical reference, data base it consisted of and research objective.

Data analysis was carried out in a descriptive way (absolute and relative frequency) for the variables of bibliometric indicators. Later, 24 themes/categories were extracted from the reading of the articles' abstracts: Nursing Education, Curriculum Guidelines, Teacher Education, Expansion of Higher Education, Curriculum, Teaching-learning Process, Political-pedagogic Project, Nursing Teacher, Pedagogic Strategies, Learning Evaluation, Public Health Education, Graduate Program, Undergraduate Students, Quality/Evaluation of Higher Education, Job Market, History of Undergraduate, Distance Education, Profile of Undergraduates, Health Human Resources, Technical Education, Higher Education, Teaching-service Integration, Educational Costs, MERCOSUR. After reading the material again, these themes were rearranged in themes according with was proposed by Edital 24/2010 - Pró-ensino à Saúde/ CAPES (CAPES, 2011/2016): Health Teaching Management and Evaluation; On-site and Distance Technologies in Health Teaching; Curriculum and the Teaching-learning Process in the Graduation and Post-graduation; Teacher Education and Development in Health; Integration between University and Health Services; Integration Policies between Health, Education, Science and Technology; Undergraduates profile.

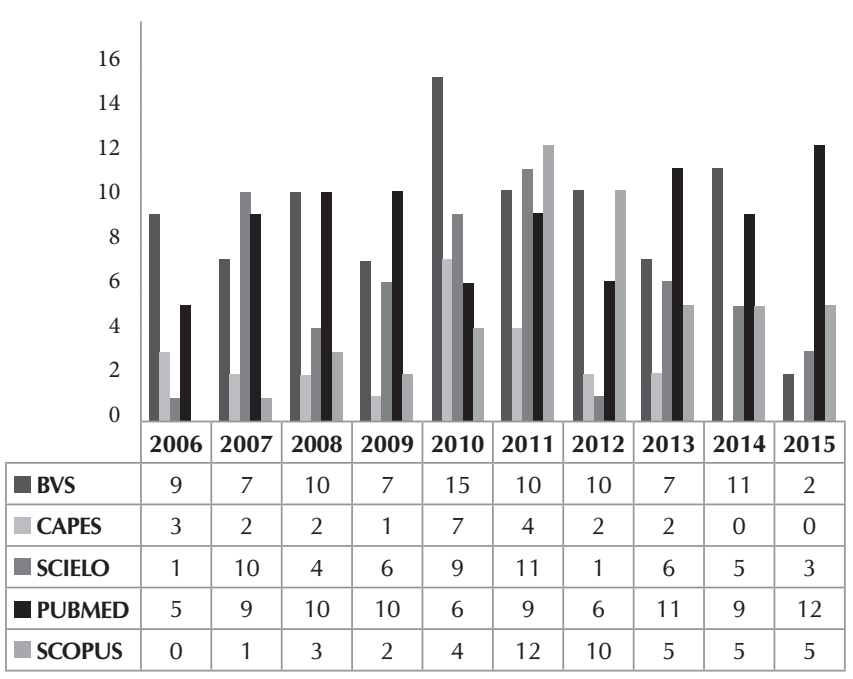

Figure 1 - Number of published articles about Nursing Professional Education, by data base and year of publication, Brazil

\section{RESULTS}

The 301 articles that compose the corpus of this study are ordered as the data base: 88 articles from BVS, 23 from Capes, 56 from SciELO, 87 from PubMed and 47 from Scopus. According to the article's year of publication, there was a gradual increasing, an average of 6.2 per year and a relevant amount in 2010 and 2011, with a simple average of 8.7, corresponding to $14.45 \%$ of the total publications identified. (Figure 1)

Among the countries of origin of the publications, Brazil points out with $84.72 \%$, followed by Chile with $5.98 \%$ and Colombia with $4.98 \%$. There is a small number of publications $(4.32 \%)$ in the others Latin American countries.

The 301 articles were published in 53 journals. Of these journals, nine stand out with the greatest number: the Revista Brasileira de Enfermagem (20.93\%), the Revista da Escola de Enfermagem da USP $(10.63 \%)$, the Revista Latino-americana de Enfermagem $(10.30 \%)$, the Revista de Enfermagem da UERJ (7.97\%), the Revista Gaúcha de Enfermagem (6.98\%) and the Revista Texto e Contexto da UFSC (6.64\%), all published in Brazil; as well as, the Revista Ciencia y Enfermeria, from Chile (3.99\%), the Revista da Escola de Enfermagem Anna Nery, from Brazil, e the Revista Investigación y Educación en Enfermería, from Colombia (3.32\%).

Regarding the sort of research, there was a higher number of qualitative studies, $79.07 \%$ of the articles and quantitative studies, $16.94 \%$.

Regarding theoretical reference, 276 out of the 301 selected articles, did not specified it in the abstracts $(91.69 \%)$. Four articles cite the reference of Phenomenology of Merleaut-Ponty $(1.33 \%)$, followed by Martin Heidegger and Edgar Morin, cited in three articles (1\% each) and the Problematizing Pedagogy and the Dialectical Materialist Methodologies, cited in two articles ( $0.66 \%$ each).

With respect to the themes, the 301 articles were sorted by and arranged in according to the Figure 2 . 
Each of the themes consist of the assortment of relevant topics:

1. Health Teaching Management and Evaluation: this theme gathers studies about management, quality and evaluation of higher education, as well as history of higher education. In this item were gathered 33 articles: 14 about Higher Education Expansion (42.42\%); 13 about Higher Education (39.39\%); 5 about Higher Education Quality and Evaluation (15.15\%); and 1 about Educational Costs (3.03\%).

2. On-site and Distance Technologies in Health Teaching: it gathers studies about methodological technologies used in higher education, including distance teaching. Were found 6 articles with this theme $(1.99 \%)$.

3. Curriculum and the Teaching-learning Process in the Graduation and Post-graduation: it groups studies about the curriculum of graduation and post-graduation courses, as well as about teaching-learning process and development of knowledge of the research groups. In this theme there high scientific production, totaling up 140 published articles: 37 about Teaching-learning Process (26,.43\%); 29 about Pedagogic Strategies (20.71\%); 23 about Post-graduation (16.43\%); 20 about Curriculum (14.29\%); 15 about Curriculum Guidelines (10.71\%); 9 about Learning Evaluation (6.43\%); and 7 about Political-pedagogic Project (5\%).

4. Teacher Education and Development in Health: aim to identify how is the teacher education and the nursing teacher. In this category were found 14 published articles about Teacher Education $(51.81 \%)$ and 13 about Nursing Teacher (profile) $(48.15 \%)$.

5. Integration between University and Health Services: studies that approaches the service-teaching integration, as well as about Human Resources Education and job market. Were found 19 articles: 10 about Job Market (52.63\%); 5 about Human Resources Education (26.32\%); 3 about Service-Health Integration (15.79\%); and 1 about MERCOSUR (5.26\%).

6. Integration Policies between Health, Education, Science and Technology: studies about policies and its influence on the education processes. This theme consists of: 30 articles about Nursing Education (60\%); 18 about Education for Public Health (36\%); and about 2 Technical Education (4\%).

7. Undergraduates profile: it groups studies that approach different issues regarding undergraduates students, totaling up 26 articles: 21 about Undergraduate Students (opinions, expectations and perceptions)(80.77\%); and 5 about Undergraduates profile $(19.23 \%)$.

This description of results permits to recognize the emphasis given to the curriculum, besides other themes and only $2 \%$ of the total publications searched according to the theme related to technologies in education. It explains the need for research improvement in this theme.

\section{DISCUSSION}

The development of knowledge about the theme of nursing professional education in MERCOSUR confirms the same trend of production in nursing research in general. The larger Brazilian production (and publication) was also identified in other studies, being pointed out as resulting from the greater Brazilian tradition in Education of Nursing Masters and Doctors. That is because it is recognized the importance of such education for development of research in the area ${ }^{(5-7)}$.

In turn, the greatest number of researches, with qualitative approach in nursing education researches, are in contrast to the hegemonic model in health practices and clinical researches. The health sector is characterized by the positivist and logical approach, in which its methods require proof, quantification, rational and objective criteria. It is guided by a Cartesian-Newtonian view, in which all genuine knowledge is based on experience/observation and reason ${ }^{(8)}$. In contrast, the interpretivist or comprehensive perspective support the subjectivity and sensitivity in developing knowledge. The philosophical movement that supports this paradigm understand the reality and the phenomena of multiple way and with holistic view, contextualized and without subject-object separation. Perhaps the nature of the phenomenon, education, based on its education in the social sciences, determines this dominance ${ }^{(9)}$.

With regard to the themes, the Management and Evaluation in Health Education featured 5 articles, 2 from Brazil and 3 from Chile and Colombia. The assessment of higher education institutions in Brazil, still is a growing field and is a process whose started in the 1970's, especially regarding postgraduate and research system. However, it was in the 1990's - so much more recent - the global assessment process of the institutions ${ }^{(10)}$.

In Brazil, in 2004, was created by Law No. 10,861 of April 14, 2004, the National Evaluation System of Higher Education (SINAES), consisting of three main components: evaluation of institutions, courses and students' achievement. This system present a set of evaluation, including the National Assessment of Student Achievement (ENADE) and the assessment of undergraduate courses, of which objectives were to improve the teaching quality in the institutions ${ }^{(11)}$.

The theme On-site and Distance Technologies in Health Education presented the smaller number of studies, what may be explained due the theme topicality. It shows a need for detailed discussions, considering the last years' increase in development of researches, publications and discussions about distance education in others areas. In this way, it is realized the theme approach has been very modest in MERCOSUR, so as in Brazilian Nursing, as notice Rojo et $\mathrm{al}^{(12)}$. In comparison with has been produced abroad in European countries and the United States of America, the MERCOSUR and Brazilian production is still distinct. Fleury ${ }^{(13)}$ notice that, while the developing countries emphasizes the quantitative expansion of education based on technologies, countries such as United Kingdom and the United States of America - as well as some other European countries - has already devoted more energy into qualitative evaluation of innovations.

Although there is legal support, in Brazil, regarding this modality, still exists resistance to this type of higher education, 
especially in health field. It is due to deep concern about technical education (skills) and pedagogical quality education of this modality. The use of Information and Communication Technologies (ICT) are also modest and scarce in the on-site education.

Some examples of actions that can improve the students' skills and competences desired are: encouragement for studying before classes; emphasis on web sites; learning to encourage the use of platforms; students' autonomy during the teaching-learning process; teaching based on problem solutions and innovative methodologies ${ }^{(14)}$.

With regards to publications related to the theme Graduation and Post-Graduation Teaching-learning Process, there is some vulnerability in learning evaluation. The topic of student's evaluation is considered a critical issue for the teachers.

The assessment of learning is included in a broad and complex context that involves many instances (micro and macro) and have distinct responsible elements, which determines how the student is evaluate ${ }^{(15)}$. In addition to that is the opportunity of learning trough dialogical and changing methodologies that allows the student to develop skills, competences and attitudes to become a critical and reflexive professional. there is a need to understand the evaluation must to be a process to be developed during the learning, for monitoring the teaching-learning process and not just be qualifying and/or discriminatory. This type of analysis and production is essential for pedagogical development in lines of Nursing Education action.

Including this line of action, other topic that highlights, for small number of publications (5\%), is about the Pedagogical Project of Course (PPC). The PPC is the main political and technical instrument and should be set up collectively in the institution. It must be political, because it determines the choices of the academic in its education; and must be pedagogical, because it determines the methodological actions that will make the student to achieve the desired learning. It is expected the education of a professional, citizen capable of thinking and reflecting about the world ${ }^{(16)}$. The PPC of a course is the mains reference point to create the identity of professional. It is the basis for the development of future critical citizens and of ethical and skilled professionals ${ }^{(17)}$. It is an important fact, as the topics about Teaching-learning Process and Pedagogical Strategies fulfil $47.14 \%$ of the publications in this line. It may indicate our concern about the implementation of teaching, but our disregard of philosophical-pedagogical foundations that maintain it. International studies focus on relationship between student and educators, what strengthen the philosophical analysis.

On of the challenges for the higher education schools is to develop professionals geared to health public policies, and that are competent, critical and reflexive. In Brazil, this challenge is together with changes in higher education as the National Education Guidelines and Framework Law (LDB) in 1996 - Law No. 9.394/96, which set out the guidelines and national education bases and the National Curriculum Guidelines (DCN) for the Nursing Graduation Education in $2001^{(18)}$. From this two legal boundaries (LDB and $\mathrm{DCN})$, the education model started to present changes, always following the current political-economic-social model in the country.

Over the 30 years - that includes the VII National Health Conference, in 1986, the Federal Constitution of 1988 and the
Law 8080 of 1990 -, the Higher Education Institutions (HEI) has been adapting to this new proposal of education. It is, to train nurses with a humanistic, critical and reflexive view, committed to and capable of acting with social responsibility in health promotion ${ }^{(19)}$. This student's education - based on the knowledge development and the pragmatic changes and reality transformation - consists of a great challenge, which is to train professional with competence, technique and policy ${ }^{(20)}$.

In regard to Teacher Education and and Development in Health, there is still early concern about the teacher education $(9 \%$ of publications). However, the education of teachers in health field is a theme little discussed. The early education of the nurse does not prepare for teaching, but for professional practice. The nurse plays a role of teacher without having specific education to develop required pedagogical competences. The theme has bringing discussions up in academic community and recent studies has shown its importance for setting up an education system in nursing consistent with pedagogical quality requirements ${ }^{(21-23)}$.

The teachers nurses become teacher, usually, in consequence of their professional activities and also to supplement salary, to obtain new opportunities of work and to keep studying. The professional nurse often plays a role of teacher without having the required pedagogical education for that. However, to be a teacher requires more than to be a good professional. To be a teacher, is necessary to have specific competences that are beyond the skills required to be a good nurse ${ }^{(24-25)}$.

Postgraduate education stricto sensu develops qualified teachers and fosters scientific researches, aiming to qualify professional teachers for teaching and assistance professionals directed for the job market ${ }^{(26)}$.

The Integration between University and Health Services is a theme of increasing importance in the training of health professionals. In Brazil, this articulation became the major player from The National Curriculum Guidelines (DCN) that points to the nurse education in accordance with the health national policies - the Unified Health System (SUS). That is because, so that the nurse contributes to an effective application of principles that guides the SUS, he needs to know, understand and include such principles in their daily practice, regardless their field of practice and in different complexity levels of health ${ }^{(20)}$. In addition, the relation between the teaching processes and the service delivery provides a unique education for the academics. They begin to experience the challenges of SUS's principles embodiment in primary health care, promoting development of human resources to act in system's service network ${ }^{(27)}$.

The theme is a concern in other countries that consider that the alliance between an education institution and a service institution - with the aim to carry out education processes --, is a necessity to the nurses education and to the development of theoretical-practical competences in health ${ }^{(28-30)}$. These spaces for practice and internship are full of real situations, before extreme situations in which the nurse can develop their ethicalprofessional commitment, making it possible to them to develop critical analyses of rights and professional responsibilities ${ }^{(31)}$.

Thus, it is observed the studies show that, despite advances in relation to Nursing education, the best way still is to approach the academy with the workers, making them all participants 
and involved with the innovative experiences in the process of teaching-learning and in health professionals education. The importance to improve the health workers' qualification in technical-specialized and ethical-political dimensions, as well as of communication and personal interrelation, for their participation as full individuals in the world of work is the great challenge for the Nursing to gain space.

Another point to highlight in this theme is the lack of publication regarding the set of MERCOSUR countries. It is believed that, although cooperation agreements and all policies involving the South American countries, they are still far from having education programs and professional regulations in nursing leading studies and practices common to the countries of the MERCOSUR. Educational articulation between the MERCOSUR countries and the Pedagogic Political Projects of the Higher Education are potential ways to advance regional integration and to provide qualification of professions, regional citizenship and democracy ${ }^{(2)}$.

Regarding Integration Policies between Health, Education, Science and Technology there was a significant number of publications addressing the education geared to health policies.

In Brazil, it happens due to the fact the changes - starting with the context of Brazilian Sanitary Reform (1988), reformulation of the National Educational Guidelines and Framework Law (LDB) (1996), debates and development of the National Curriculum Guidelines (DCN) (2001) - led to a growing movement of reformulating and restructuring curriculum of higher education courses in health and nursing. So, the Higher Education Institutions ( $\mathrm{HEl})$ started concerning to know if the nurse education was in accordance with the DCNs and the policies of SUS, as well as with real situations, imposed by the population's needs and the health management.

Another concern of the IES was if the methodologies used was aiming to develop professionals that were critical, reflexive, independent, capable of learning to learn and of learning to be and of learning to do. Overall, if the nursing teacher had the control of innovative knowledge of pedagogical practices and continuous handling of the teaching-learning process and the guidelines of SUS ${ }^{(19)}$.

Although there is a substantial number of publication addressing this theme, it is a long road to pursuit to ensure the education based on the principles of health policies and the National Curriculum Guidelines.

In regard to the topic Undergraduates Profile $(9 \%)$, there is a small number of publication. Considering that there were important changes in the nursing education, it would be desirable that more studies expressed the students, to promote the co-responsabilization in the education. Some authors, by justifying the theme and its study, states that, to know the perception the students have about their education, is an input that helps to identify strengths and weaknesses and, from there, to create suggestions to improve the nursing professional education ${ }^{(32)}$.

Studies has shown the students are not being passives anymore. They are now empowered, individuals of their own learning, since the transformation of teaching-learning environment in a space of criticism and creativity makes the teacher and the student to deconstruct the perceptions of teaching and learning to build new possibilities and assume new attitudes. And thus, become critical, reflective and capable of promoting social and political changes in education and health. The student needs to get out of the position of knowledge receiver to take the place of protagonist of their own learning process ${ }^{(33)}$.

Therefore, it is observed that the nursing production before education for the MERCOSUR is an important element for political growth and rise of the nursing professional in Brazil and in the world. According to Cárdenas-Becerril et al ${ }^{(34)}$, professional education in nursing must respond in an efficient, full, timely, assertive and humanistic way the demands for life care and human being health care and recovery. So, it is necessary to change the curriculum and teaching methodologies in order to strengthen the skills that a nursing professional must have.

\section{Study limitations}

The classification of the articles in topic areas in this study did not took into account the interfaces, given that each article was rated on a single topic area, at the discretion of the researchers.

\section{Contributions to Nursing}

This study contributes with discussion in nursing education field when points to the themes regarding the production about nurses' education in MERCOSUR has been based on.

\section{FINAL CONSIDERATIONS}

This bibliometrics has shown that, in the last ten years, the studies have placed on the agenda the topic of professional education in nursing in different approaches in the members states of the MERCOSUR. However, there is some major issues requiring greater attention of the professional category.

The theme of curriculum was the most investigated in different aspects, which denotes concern with the organization of teaching and its offer by the IES. On the other hand, the topic of on-site and distance technologies demonstrates the smallest number of studies, while we live a boom of technological resources applied to education. This points to an important lack of knowledge, since it is necessary to establish the ICT, as well as to qualify its use in Nursing education.

Another theme that brings attention is the nursing teacher education, which continues as secondary in the set of studies developed. The recognized need for development of pedagogical skills for teaching requires the topic be an object of study. Especially, because the curriculum of undergraduate courses in nursing, in general, are directed to the education of the professional and not to the teacher of nursing. It is highlighted the need for specific training and permanent education throughout the academic career that considers both the education of the researcher (as performed in master's and doctoral courses) and the teacher of nursing.

The teaching-service integration is a topic that, although it is knows its importance in the education of new professionals, so far has no significant participation in the studies of this topic area. Although traditionally, the education of nurses is given in close coordination with the fields of practice, there are few studies on this object. At the moment we point to the importance of critical-creative and reflective education in nursing, it is not enough to think and be concerned about the education process in the HEl. It is a main importance to build new ways of entering 
the students in the fields of practice, overcoming outdated models of dressage. The context of professional practice need to be part of formative process, in a questioning perspective, for reconstruction of care and educational models.

In conclusion, the theme of Nursing Education in MERCOSUR that take into account all the countries of it, were not identified in this study (consider the inherent limitations to the cutouts established). In this regard, we highlight the need for expansion of the interinstitutional cooperation processes for the development of studies in this area, through cooperative multicenter studies, which contribute to the knowledge of the specifics of nursing education in each member countries, to successful experiences, to their strengths and needs. Studies of this type are important contributions to the strengthening of the integration processes of the MERCOSUR and, specially, to achieve the goals established in the Educational MERCOSUR agreement.

\section{REFERENCES}

1. Brasil. Página Brasileira do Mercosul: Mercosul [Internet]. 2017 [cited 2016 Jul 20]. Available from: http://www.mercosul.gov.br/

2. Schmoeller R, Schveitzer MC, Arruda C, Backes VMS, Prado ML, Martini JG. Mercosul educativo na carreira de Enfermagem. Rev Bras Enferm [Internet]. 2012[cited 2016 Jul 20];65(5):856-61. Available from: http://www.scielo.br/pdf/reben/v65n5/21.pdf

3. Figueiredo NM. Desenvolvimento e avaliação de coleções. Rio de Janeiro: Rabiskus; 1993.

4. Araújo CA. Bibliometria: evolução histórica e questões atuais. Em Questão [Internet]. 2006[cited 2016 Jul 20];12:11-32. Available from: http://seer.ufrgs.br/index.php/EmQuestao/article/view/16

5. Silva RS. Pós-graduação e a pesquisa em enfermagem na América Latina: avanços e desafios. Rev Cuid [Internet]. 2015 [cited 2016 Jul 20];6(2):1019-21. Available from: https://www.revistacuidarte.org/index.php/cuidarte/article/view/307/458

6. Bueno Robles LS, Díaz Heredia LP, Mejía Rojas ME, López L. Panorama de la formación doctoral en enfermería. Av Enferm [Internet]. 2010[cited 2016 Jul 20];28(2):134-44. Available from: http://www.revistas.unal.edu.co/index.php/avenferm/article/view/21388/22438

7. Cabral IE, Tyrrel MAR. Pesquisa em enfermagem nas Américas. Rev Bras Enferm [Internet]. 2010 [cited 2016 Jul 20];63(1):104-10. Available from: http://www.scielo.br/pdf/reben/v63n1/v63n1a17.pdf

8. Pereira RR, Miclos PV. Pesquisa quantitativa e qualitativa: a integração do conhecimento científico. Saude Transf Soc[Internet]. 2013[cited 2016 Jul 20];4(1):16-8. Available from: http://www.redalyc.org/pdf/2653/265325753005.pdf

9. Guerrero-Castañeda RF, Prado ML, Ojeda-Vargas MG. Reflexión crítica epistemológica sobre métodos mixtos en investigación de enfermería. Enferm Univ [Internet]. 2016 [cited 2016 Jul 20];13(4):246-52. Available from: http://www.scielo.org.mx/pdf/eu/ v13n4/2395-8421-eu-13-04-00246.pdf

10. Soares MSA. O sistema de avaliação do ensino superior no Brasil. In: Instituto Internacional para la Educación Superior en América Latina y el Caribe. La evaluación y la acreditación en la Educación Superior en América Latina y el Caribe [Internet]. 2014 [cited 2016 Jul 20]. Available from: http://www.unc.edu/ppaq/docs/arrosasoares.pdf

11. Brasil. Ministério da Educação. Lei $n^{\circ}$ 10.861, de 14 de abril de 2004: Institui o Sistema Nacional de Avaliação da Educação Superior - SINAES e dá outras providências. [Internet]. 2004[cited 2016 Jul 20]. Available from: http://www.planalto.gov.br/ ccivil_03/_Ato2004-2006/2004/Lei/L10.861.htm

12. Rojo PT, Vieira SS, Zem-Mascarenhas SH, Sandor ER, Vieira CRS. Panorama of nursing distance education in Brazil. Rev Esc Enferm USP [Internet]. 2011 [cited 2016 Jul 20];45(6):1476-80. Available from: http://www.scielo.br/pdf/reeusp/v45n6/v45n6a28.pdf

13. Fleury MTL, Mattos MIL. Sistemas educacionais comparados. Estud Av[Internet]. 1991[cited 06 Aug 2014];5(12):69-89 . Available from: http://dx.doi.org/10.1590/S0103-40141991000200006

14. Mota R. Educação à distância: no começo estranha-se, depois, entranha-se! [Internet]. Associação Brasileira de Educação à distância: 2016[cited 2016 Jul 20]. Available from: http://www.abed.org.br/site/pt/midiateca/textos_ead/1381/2016/05/ educacao_a_distancia_no_comeco_estranha-se,_depois,_entranha-se

15. Bernardi MC, Prado ML, Kempfer SS, Ribeiro KRB, Oliveira SN. Portfólio na Avaliação do Estudante de Graduação na Área da Saúde: estudo bibliométrico. Cogitare Enferm [Internet]. 2015 [cited 2016 Jul 20];20:153-60. Available from: http://revistas.ufpr. $\mathrm{br} /$ cogitare/article/view/38199/24865

16. Nobrega-Therrie SM, Guerreiro MGS, Moreira TMM, Almeida MI. Political Pedagogical Project: conception, construction and evaluation in nursing. Rev Esc Enferm USP [Internet]. 2010 [cited 2016 Jul 20];44(3):679-86. Available from: http://www.scielo. $\mathrm{br} / \mathrm{pdf} /$ reeusp/v44n3/18.pdf

17. Azevedo MAR, Andrade MFR, Projeto Político-Pedagógico e o papel da equipe gestora: dilemas de possibilidades. Interacções [Internet]. 2012 [cited 2016 Jul 20];8(21):204-18 Available from: http://revistas.rcaap.pt/interaccoes/article/view/1531

18. Brasil. Conselho Nacional de Educação. Câmara de Educação Superior. Resolução CNE/CES n. ${ }^{\circ} 3$, de 07 de novembro de 2001: Institui Diretrizes Curriculares Nacionais do Curso de Graduação em Enfermagem [Internet]. Brasília: CNS; 2001 [cited 2016 Jul 19]. Available from: http://portal.mec.gov.br/cne/arquivos/pdf/CES03.pdf

19. Lucchese R, Vera I, Pereira WR. As políticas públicas de saúde - SUS - como referência para o processo ensino-aprendizagem do 
enfermeiro. Rev Eletr Enf [Internet]. 2010 [cited 2016 Jul 20];12(3):562-6. Available from: http://dx.doi.org/10.5216/ree.v12i3.11144

20. Winters JRF, Prado ML, Heidemann ITSB. Nursing education oriented to the principles of the Unified Health System: perception of graduates. Esc Anna Nery Rev Enferm[Internet]. 2016 [cited 2016 Jul 20];20(2):248-53. Available from: http://www.scielo.br/ pdf/ean/v20n2/1414-8145-ean-20-02-0248.pdf

21. Backes VMS, Moya JLM, Prado ML, Menegaz JC, Cunha AP, Francisco BS. Expressions of pedagogical content knowledge of an experienced nursing teacher. Texto Contexto Enferm [Internet]. 2013 [cited 2016 Jul 20];22(3):804-10. Available from: http://www. scielo.br/pdf/tce/v22n3/v22n3a29.pdf

22. Canever BP, Prado ML, Gomes DC, Jesus BH. Epistemological world awareness of healthcare faculty. Rev Gaúcha Enferm [Internet]. 2016 [cited 2016 Jul 20];37(3):538-11. Available from: http://www.scielo.br/pdf/rgenf/v37n3/0102-6933-rgenf1983144720160353811.pdf

23. Menegaz JC, Backes VMS, Medina JL, Prado ML. Pedagogical practices of good nursing, medicine and dentistry professors from the students' perception. Texto Contexto Enferm [Internet]. 2015[cited 2016 Jul 20];24(3):629-36. Available from: http://www.scielo. br/pdf/tce/v24n3/pt_0104-0707-tce-24-03-00629.pdf

24. Reibnitz KS, Prado ML. Inovação e educação em enfermagem. Florianópolis: Cidade Futura, 2006.

25. Lazzari DD, Martini JG, Busana JA. Teaching in higher education in nursing: an integrative literature review Rev Gaúcha Enferm [Internet]. 2015 [cited 2016 Jul 20];36(3):93-101. Available from: http://www.seer.ufrgs.br/index.php/RevistaGauchadeEnfermagem/ article/view/49670/35064

26. Erdmann AL, Fernandes JD, Teixeira GA. Panorama da Educação em Enfermagem no Brasil: graduação e pós-graduação. Enferm Foco [Internet]. 2011 [cited 2016 Jul 20];2(Supl):89-93. Available from: http://revista.portalcofen.gov.br/index.php/enfermagem/ article/view/91/76

27. Pizzinato A, Gustavo AS, Santos BRL, Ojeda BS, Ferreira E, Thiesen FV, et al. Integração Ensino-Serviço como Estratégia na Formação Profissional para o SUS. Rev Bras Educ Méd[Internet]. 2012 [cited 2016 Jul 20];36(1):170-7. Available from: http://www.scielo.br/ $\mathrm{pdf} / \mathrm{rbem} / \mathrm{v} 36 \mathrm{n} 1 \mathrm{~s} 2 / \mathrm{a} 25 \mathrm{v} 36 \mathrm{n} 1 \mathrm{~s} 2 . \mathrm{pdf}$

28. Salgado Paris JE, Sanhueza Alvarado O. Enseñanza de la enfermería y relación docente asistencial en el marco educacional y sanitario chileno. Invest Educ Enferm [Internet]. 2010[cited 2016 Jul 20]:28(2):258-66. Available from: http://www.redalyc.org/ articulo.oa?id $=105215405012$

29. Garnica L, Ballistreri M, Vítola D, Tria M, Pippino M, Meza H. ¿Existe la integración docente asistencial en enfermería? Enferm[Internet] 2013[cited 2016 Jul 20];1(3):161-7. Available from: https://revistas.ucu.edu.uy/index.php/enfermeriacuidadoshumanizados/article/ view/868/871

30. Valenzuela-Suazo S. La práctica de enfermería como foco de reflexión. Aquichán [Internet]. 2016 [cited 2016 Dec 20];16(4):415-7. Available from: http://www.redalyc.org/pdf/741/74148832001.pdf

31. Lima MM, Almeida AB, Giovannetti MO, Backes VMS, Kloh D. Produção do conhecimento acerca da formação do enfermeiro: um estudo bibliométrico. Rev Bras Enferm [Internet]. 2012[cited 2016 Jul 20];65(3):522-8. Available from: http://www.scielo.br/ pdf/reben/v65n3/v65n3a19.pdf

32. Cáneo M, Brizuela MJ, Muñoz P, Pérez G, Solsona D. Percepción del ambiente educacional preclínico em estudiantes de $1^{\mathrm{a}}$ a $4^{\mathrm{a}}$ año de enfermería de la Universidad Diego Portales, Santiago (Chile). Rev Iberoam Educ Invest Enferm [Internet]. 2016 [cited 2016 Jul 20];6(2):37-45. Available from: http://www.enfermeria21.com/revistas/aladefe/articulo/201/

33. Waterkemper R, Prado ML, Medina JLM, Reibnitz KS. To be the shadow - awareness of undergraduate nursing students: a case study. Texto Contexto Enferm [Internet]. 2015[cited 2016 Jul 20];24(4):1079-86. Available from: http://www.scielo.br/pdf/tce/2015nahead/ pt_0104-0707-tce-201500003900013.pdf

34. Cárdenas-Becerril L, Porras MDB, Gómez MAJ, Püschel VAA, Rojas AM, Ortega JL. Presencia del pensamiento reflexivo y crítico en los currículos de Enfermería en Iberoamérica: una visión cualitativa. Atas CIAIQ [Internet] 2016 [cited 2016 Jul 20];1:128-37. Available from: http://proceedings.ciaiq.org/index.php/ciaiq2016/article/view/596/585 